\title{
THE ROLE OF THE EMPLOYEE IN HUNGARIAN HOSPITAL PERFORMANCE APPRAISAL SYSTEMS ${ }^{* *}$
}

\author{
(Received: 8 March 2021; accepted: 31 July 2021)
}

In this paper, we examined the employee Performance Appraisal System (PAS) of hospitals and gave a description of the role and significance of employees in the PAS covering $27 \%$ of the population of Hungarian state-run hospitals. In the research, we also examined the relationship between performance appraisal and employee engagement, as well as the practice of measuring employee satisfaction. We created a scale called Employee participation in the employee performance appraisal scale. Based on our findings, we can state that the employee is an active participant in the Hungarian performance appraisal systems of hospitals, as they are involved in the appraisal and their views are taken into account. It has been found that where employee satisfaction is measured, there is an opportunity for the employees to formulate reflections on their evaluations. Although not outstanding, the employee is considered a partner in the evaluation of his work.

Keywords: performance appraisal systems; employee engagement; employee satisfaction measurement; Hungarian; hospital

\section{Introduction}

Planning is an integral part of all management activities, thus strategic human resource management requires foresight to better meet organizational and individual needs. This kind of (novel) approach allows the organization to see its employees as strategic partners, using their knowledge as a competitive advantage in a market

* Corresponding author: Norbert Zétény Sárga, PhD School of Semmelweis University, Doctoral School of Mental Health Sciences, No. 4/3. Program, Budapest Üllöi u. 26, 1085-Hungary (Sociological and mental health approaches to resources for individuals and communities); sarga.zeteny@semmelweis-univ.hu.

** For the research, we received permission and support from the state maintainer, the State Health Care Center. The research was reviewed by the Scientific and Research Ethics Committee of the Health Science Council of Semmelweis University and, given that it is not aimed at questioning either health or personal data, was not considered to be within its remit. Acknowledgments: We would like to thank the management of the Hungarian hospitals for their active participation in the research. Special thanks to Dr. Gyula Bakacsi for his help. We also thank the reviewers for their valuable remarks. 
environment (KARIITHi \& OGUTU 2016). For this reason, we consider employee engagement to be an important factor in a successful organization, including hospitals.

Performance appraisals are regular reviews of employee performance within an organization (PATIL \& DALVi 2019). Performance management (PM) 'will help you to create and sustain high levels of employee engagement, which leads to higher levels of performance' (GRUMAN \& SAKS 2011, 133). We conducted a large, exploratory, descriptive study of Hungarian employee performance appraisal systems in Hungarian hospitals. In the research, we also examined the practice of measuring employee satisfaction. Accordingly, we also studied how employee satisfaction measurement is related to performance appraisal. The aim of this publication is to present the importance and role of the employee in Hungarian hospital performance appraisal systems: how active the employee is in the evaluation, how much the employee is considered as a partner.

To our knowledge, no such hospital research has so far been conducted in Hungary.

\section{Theoretical framework}

\subsection{Performance appraisal}

The harmony of institutional and individual goals is essential in the operation of a successful institution and organization (BAKACSI 2015). Without performance appraisal, it is difficult to measure the achievement of institutional goals and an individual's performance. Work can be evaluated in two ways: formally and informally (BoKoR et al. 2009). In the world of work, informal evaluation (such as verbal praise) is part of organizational culture (TAKÁCs 2000). Formal evaluation can be an objective element of the employee's career development and the assessment of any employee benefits and rewards, and can also clarify the expectations placed on the employee. On the employer's part, it helps to maintain and increase performance, not only by identifying and improving the factors that hinder and complicate work, but also by motivating and developing employees (Boncz et al. 2011). The performance appraisal system (PAS) can therefore also be seen as an organized 'communication channel' provided to the employer and the employee (KAROLINYNÉ \& PoÓR 2010, 290). Information gathered through this channel also helps the organization make efficient use of the limited resources.

\subsection{Performance appraisal and employee engagement}

It has been known since Herzberg that work achievement, performance, and its recognition act as motivating factors for the employee (BAKACSI 2015). While several definitions of commitment are known, we prefer the definition of GYÖKÉR and KRAJCSÁK (2009, 59): 'Commitment is most often an action form of satisfaction; innovative, creative, 
value-creating behavior created as a result of internal motivation in order to achieve the organizational goal.' Employee commitment and satisfaction are closely related, but they are not synonymous (GYÖKÉR \& KRAJCSÁK 2009). In our interpretation, employee satisfaction is the foundation from which employee engagement develops. The key moment in this process is an essential element of performance appraisal. HsiEH (2016) also confirmed in his study that job performance and job satisfaction significantly influence each other. Assessment is not only a cognitive process because it also has a sociological and an organizational context (JENKINS 2005). Appraisal is typically influenced by an individualization process. Evaluation - as people's work is considered and judged - must also be well-thought-out psychologically. The 'Achilles heel' of human capital management is PM (GRUMAN \& SAKs 2011, 123). Employee engagement is often seen as a key factor in an organization's success and competitiveness. In relation to performance appraisals, the study by HERMEL-STĂNESCU (2015) illustrates well the importance of aligning individual and institutional goals. The author states that a properly constructed and implemented PAS is a critical success factor for companies and organizations in the business world. PM is geared towards the future; in the direction of developments, not simply in an evaluation of the past. It is a continuous and evolutionary process through which performance improves over time. This is what the author calls 'the performance management cycle'. The stages of this cycle are: performance and development planning, performance measurement, goals, and goal integration. An essential part of the process is the acceptance of performance evaluation by employees and its facilitation. Acceptance of appraisal is influenced by, among other things, the quality of the relationship between the evaluator and the evaluated; the opportunity to participate in the evaluation process (agreement on the performance to be achieved); perception of empowered employees, and perception of objectives (KIm 2014). If managerial decisions reward the work done with fair and equitable rewards as well as advancement, it increases employee engagement and loyalty to the organization (SALAU et al. 2014). In the same spirit, should employees be sufficiently motivated towards necessary and appropriate training, work-related innovation will increase, thereby helping the organization gain a competitive advantage. In addition, employees agree that receiving regular feedback on their performance in the workplace can make an organization sustainable. This also helps them to identify their strengths and weaknesses (SALAU et al. 2014). Hospital research by BIBI and KHAN (2019) also supports that PA itself influences employee performance.

The issue of performance appraisal affecting employee motivation is also addressed in JABEEN (2011) in his study. He says inspiration can come not only from the outside (in the form of increased pay) but also from internal factors. Internal factors include gratitude, fulfillment, and accomplishment. MisiaK (2010) acknowledges that performance appraisal is one of the most important tools for human resource management, but a poorly constructed and implemented PAS can be more harmful than useful. Ethical appraisal is fair and objective. Implementing this ethical assessment is 
an extremely difficult task, but it is possible. NuRE (2018) finds that the continuous and fair appraisal of employees is related to their motivation and further job performance.

The design and operation of a well-functioning PAS is a basic requirement. Determining aspects must be taken into account during design. These are: it is necessary to first define the performance itself; decide whether the evaluation should be based on a performance management goal; identify the different performance evaluation techniques to be used in the evaluation and select the participants in the evaluation. There may be many participants in the appraisal, but the primary actor is the evaluated boss, immediate superior, and workplace leader. Based on his/her task, he/she has the best opportunity to see the evaluated work, but he/she is also aware of the obligations assigned to the employee and the requirements placed on him/her (Bokor et al. 2009; KArolinyné \& Poór 2010; Boncz et al. 2011). Because the employee's active participation remains essential in a well-functioning PAS; employee engagement is the foundation not only of the way one works, but also of the evaluation of the work one does. For this reason, employee appraisal and self-appraisal should be an integral part of the evaluation process. One of the arguments in favor of self-appraisal is that the employee is closely aware of his/her motivation and has sufficient information about his/her own work (BOKOR et al. 2009).

In their own empirical study of hospital workers, SING and VADIVELU (2019) found that $85 \%$ of workers think PA is useful. It is also important that employees receive appropriate training or counselling after the assessment.

\subsection{Hypotheses}

Based on the theoretical background and literature review, we formulated three hypotheses:

- H1: The majority of hospitals measure employee satisfaction.

- H2: During the performance appraisal in hospitals, the employees have the opportunity to formulate reflections.

- H3: Where there is an employee satisfaction measurement, the employee also has the opportunity to formulate reflections.

Our further research questions are presented in the Methodology section.

\section{Research background}

The present research has two antecedents. The first author, as an acting manager, performed a performance appraisal at the Central Physiotherapy Department of the Nagykörös Rehabilitation Specialist Hospital. The performance evaluation was carried out on the instructions of the Directors-General. The results of the performance evaluation were presented (SÁRGA 2016). This was followed by an 
exploratory study in the hospitals located in the Hungarian Dél-Alföld Region. The focus of the research was to learn about and present different performance appraisal practices. The results of this research have also been published (SÁRGA 2017). The valuable experience gained during the research has been incorporated into the current study.

\section{Methodology}

We examined Hungarian, state-run hospitals, assuming that they perform employee performance appraisals and that appraisal can be analyzed. We also examined the extent to which the employee appears in the development and operation of PAS and how integral the employee is to the evaluation process. We were curious about the prevalence of employee satisfaction measurement in Hungarian hospitals. We also examined the relationship between PAS and employee satisfaction measurement. At the time of the study, no mandatory and uniform performance evaluation existed in Hungarian hospitals. It was the management's own decision whether their institution had a performance appraisal and, if so, what features worked in it.

We performed data collection using a questionnaire method. In compiling the questionnaire, we took into account the literature and available professional materials. We also crafted it for the study of the already-mentioned Dél-Alföldi Region. The questionnaire was sent to the directors general of the state-run hospitals on a paper basis. During the study period, we identified 114 hospitals that we wanted to include in the research. The response was voluntary and anonymous. The completed questionnaires were intentionally returned to the research participants and not to the maintainer. The survey was conducted in August and September 2018. Our research questions and aspects can be found in Table 1 .

Table 1

Research questions

\footnotetext{
1. Did the evaluated person participate in the development of the performance appraisal system?

2. Does the evaluated person participate in the updating and review of the performance appraisal system?

3. Is there an employee satisfaction measurement in the hospital?

4. If so, how often?

5. Does the evaluated person participate in your performance appraisal system?

6. Does the evaluated employee receive feedback on the performance appraisal?

7. Does the employee have the opportunity to formulate reflections on his or her appraisal?
} 
For the questions distribution in the development of the PAS, review of the PAS, feedback, and reflections, multiple choices were offered; in the question employee satisfaction measurement, there were 4 (ordinal scale), in the question frequency of employee satisfaction measurement: six options; and a 4-point Likert scale was used to rate question participants in the appraisal.

Based on previous managerial and research experience, in order to get a more nuanced picture of employee participation in PAS, we weighted the variables with the exception of question 4 , which asks about the frequency of employee satisfaction measurement. The variables and the weights assigned to them are shown in Table 2. The focus of our research has been active employee participation, and we believe that performance appraisal can be effective if it is done in cooperation with the employee. For this reason, it is recommended that the employee be actively and meaningfully involved in the development and review of the performance appraisal system and in the appraisal process itself. We consider it essential that the employee receive relevant feedback on the evaluation. In connection with this, another important and forward-looking aspect is that the employee has the opportunity to formulate reflections. We believe that it is crucial that hospitals have employee satisfaction measurements - and, where available, provide meaningful information, and that the information derived from it is used in a management decision.

Table 2

The weighted variables

\begin{tabular}{lc}
\hline Name of the variable & Variable weight \\
\hline Did the evaluated participate in the development of the performance appraisal system? & 1 \\
Does the evaluated person participate in the updating and review of the performance & if yes \\
appraisal system? & 1 \\
Is there an employee satisfaction measurement in the hospital? & 0 \\
No. & 0,1 \\
Yes, but the information obtained from it may be used occasionally. & 0,5 \\
Yes, and we often base decisions on it. & 1 \\
We consider it important, measure it, and use the results obtained from it. & \\
Does the evaluated person participate in your performance appraisal system? & 0,1 \\
Does not participate in the appraisal. &
\end{tabular}


Participate, his/her opinion is decisive.

Does the evaluated employee receive feedback on the performance appraisal?

Yes, orally.

Yes, in writing.

Yes, in both forms.

No, in any form.

Does the employee have the opportunity to formulate reflections on his or her appraisal?

No.

\section{Results}

The questionnaire was returned by a total of 31 hospitals. Response rate is $27 \%$. The exact response rates for the different questions are shown separately. Nearly $13 \%$ of evaluators are involved in the development of the PAS, but they are no longer involved in its review. The distribution of the other participants is shown in Table 3.

\section{Table 3}

Distribution of participants in the development and revision of the performance appraisal system (expressed as a percentage of respondents)

\begin{tabular}{lccccccc}
\hline & $\begin{array}{c}\text { Top manager } \\
(s)\end{array}$ & $\begin{array}{c}\text { HR } \\
\text { department }\end{array}$ & $\begin{array}{c}\text { Workplace } \\
\text { manager }(s)\end{array}$ & Employees & Colleagues & $\begin{array}{c}\text { External } \\
\text { company }\end{array}$ & Others \\
\hline Development of & 64,52 & 38,71 & 32,26 & $\mathbf{1 2 , 9 0}$ & 12,90 & 16,13 & 6,45 \\
In its review & 54,84 & 38,71 & 29,03 & $\mathbf{0 , 0 0}$ & 3,23 & 12,90 & 6,45 \\
\hline
\end{tabular}


In connection with the measurement of employee satisfaction, it can be stated that more than a third of the surveyed institutions consider it important, measure it, and use the data obtained from it. There is an equal proportion of employee satisfaction measurements, but the information obtained from it may be used occasionally. It can be stated that few hospitals have no measurement of employee satisfaction at all. The first hypothesis was thus verified. In detail, in Figure 1.

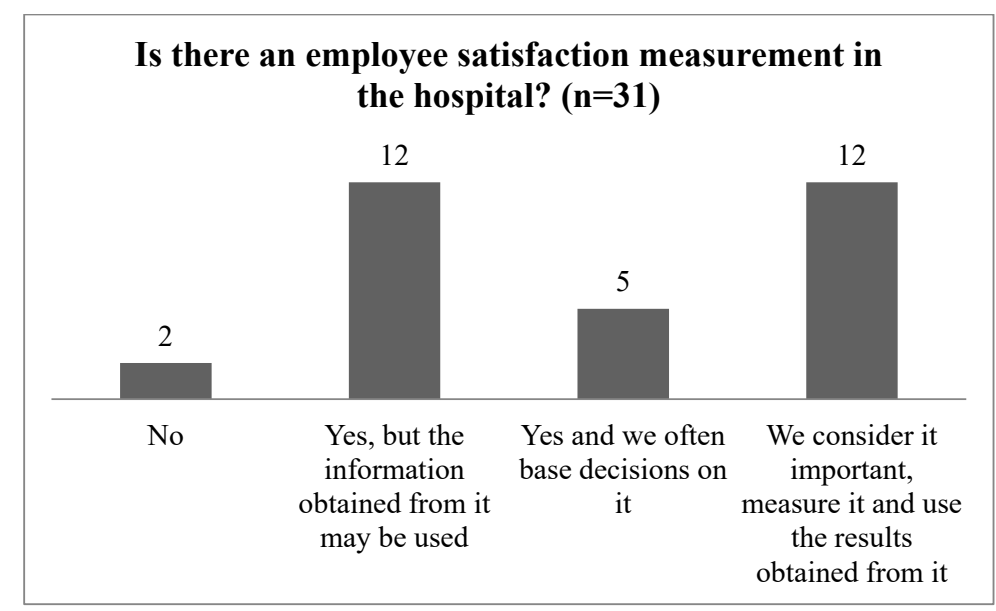

Figure 1

Measuring employee satisfaction

Employee satisfaction is measured annually in just over half of the cases $(\mathrm{n}=$ 18). In two cases, the measurement is done quarterly and half a year, respectively. In seven cases. it was done less frequently and in two cases, no employee satisfaction was measured. The participants of the evaluation system can be divided into two groups. In one group are those who are actively involved in the evaluation and their opinions are decisive. The other group includes those who are practically not involved in the evaluation as well as less active participants in the evaluation system, whose opinions are aleatory. Regarding the participants in the appraisals, it was found that the opinion of the workplace's evaluated direct supervisor is the most decisive, followed by that of the evaluated employer, and then the evaluated person himself. In detail Table 4. 
Table 4

Participants in the appraisal

\begin{tabular}{|c|c|c|c|c|c|}
\hline & $N$ & Minimum & Maximum & Mean & Std. Deviation \\
\hline Workplace manager & 25 & 1 & 4 & 3,52 & 0,714 \\
\hline Employer & 25 & 1 & 4 & 2,52 & 1,262 \\
\hline Self-appraisal & 25 & 1 & 4 & 2,48 & 1,295 \\
\hline HR department & 25 & 1 & 3 & 1,36 & 0,569 \\
\hline Colleagues (s) in the identical position & 24 & 1 & 3 & 1,42 & 0,654 \\
\hline Colleagues (s) in the non-identical position & 25 & 1 & 3 & 1,28 & 0,542 \\
\hline Patients treated by the employee & 25 & 1 & 3 & 1,52 & 0,823 \\
\hline Others & 9 & 1 & 3 & 1,22 & 0,667 \\
\hline
\end{tabular}

1: not involved; 4: most important.

Regarding the feedback of the appraisals, it can be said that almost half of the evaluated employees receive feedback, both in writing and orally. Detailed distribution in Figure 2.

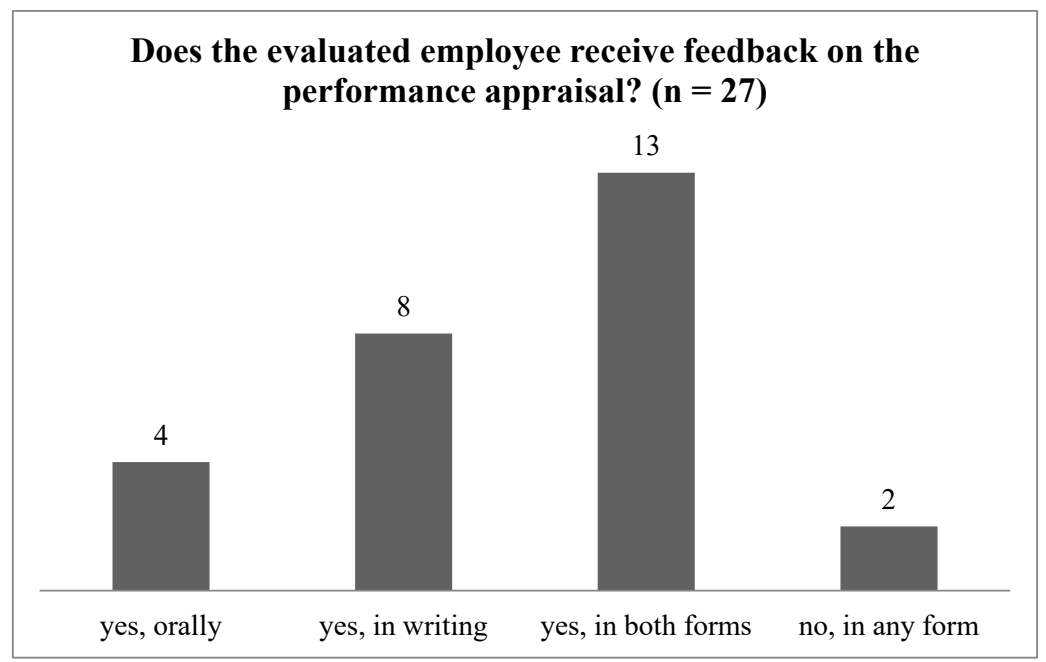

Figure 2

Feedback on the appraisal 
We also asked to what extent the employee has an opportunity to formulate reflections on the evaluations. They have a vast majority of options, and they are somewhat taken into account. It can be stated that in a few cases the employee has no - or only possibly - the opportunity to formulate reflections. The second hypothesis was also verified. The total distribution is shown in Figure 3.

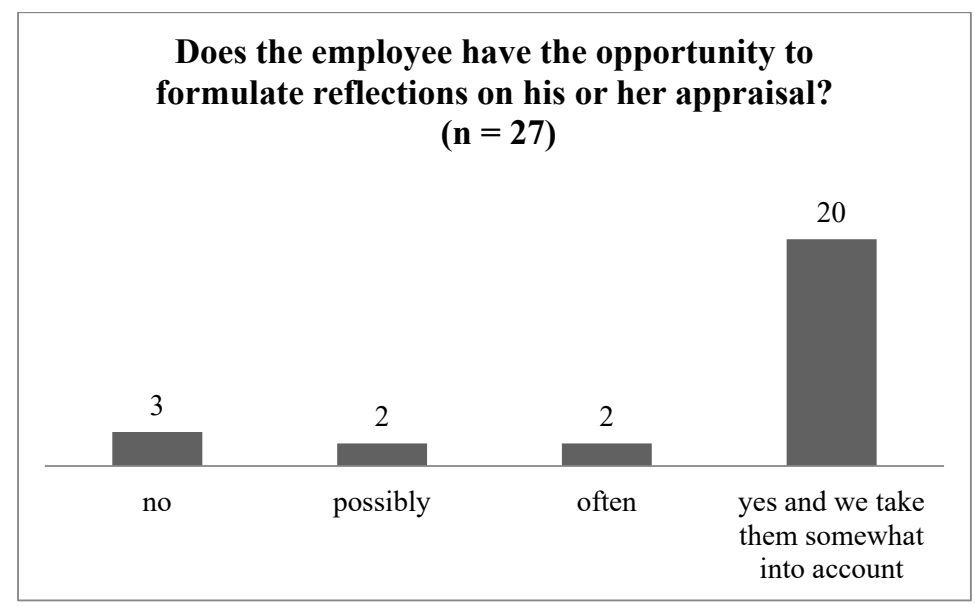

Figure 3

Reflections on appraisal

The weighted variables mentioned above were placed on a scale called Employee participation in employee performance appraisal. Analyzing the responding hospitals, it can be stated that the participation of employees in the appraisal of employee performance in Hungarian hospitals could be considered moderate: the average of the variable measured on a $0-1$ scale is 0.437 , the distribution median is 0.323 (= thus half of the respondents are below and the other half of the sample is above this level). This is also supported by the distribution diagram in Figure 4.

Based on the analysis of the obtained results, it was found that where there is an employee satisfaction measurement, an opportunity exists for the evaluated person to formulate reflections (and they are taken into account to some extent). The third hypothesis was also confirmed. This statement can be verified, and it can be clearly seen in Table 5; but the statistical analysis (both chi-square test and phi test) is not significant ( $\mathrm{p}=0.152$ for both) (this is due to the low number of sample items, because the correlation is otherwise clearly visible). We also tried Fisher's exact test to show whether there is a relationship between the two variables. Considering the significance level of Fisher's test $(p=0.324)$, we have no grounds to reject the null hypothesis that states there is no association between employee satisfaction measurement and reflections. 


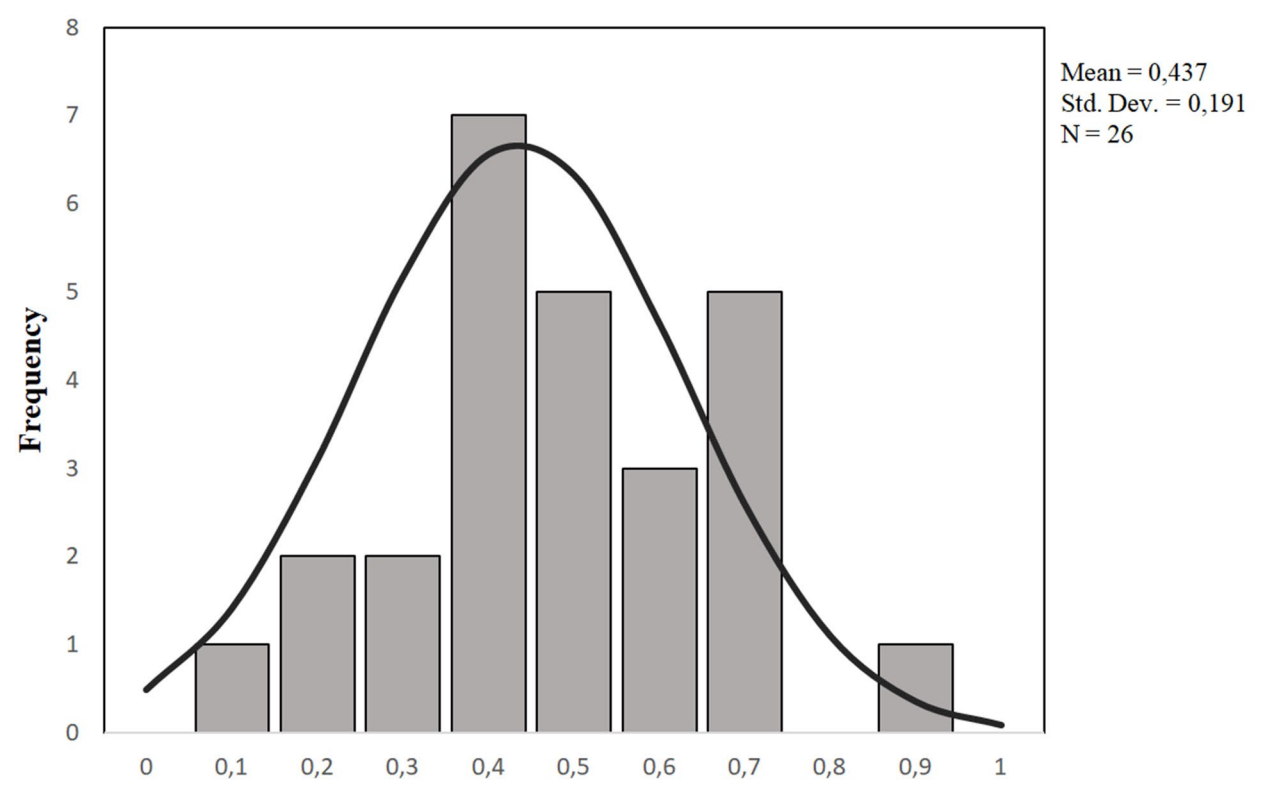

Employee participation in employee performance appraisal scale

Figure 4

Distribution of employee participation in employee performance appraisal

\section{Discussion and conclusion}

It is far-sighted that employees have been involved in the development of the PAS, but it is thought-provoking that there are no longer any employees involved in the system's further development. We recommend that evaluated employees be involved in the review of the appraisal system as they certainly have experience, whether positive or negative, of the appraisal process itself. For an effectively functioning PAS, it is essential to be clear about whether the evaluation is being done in accordance with the desired PM objectives, and whether the system is suitable for measuring worker performance. In the previous research section, we noted that an employee PA was performed at the Nagykörös Rehabilitation Specialist Hospital. After the evaluations were completed, a much shorter survey was conducted to examine how 
Table 5

Employee satisfaction measurement vs reflections

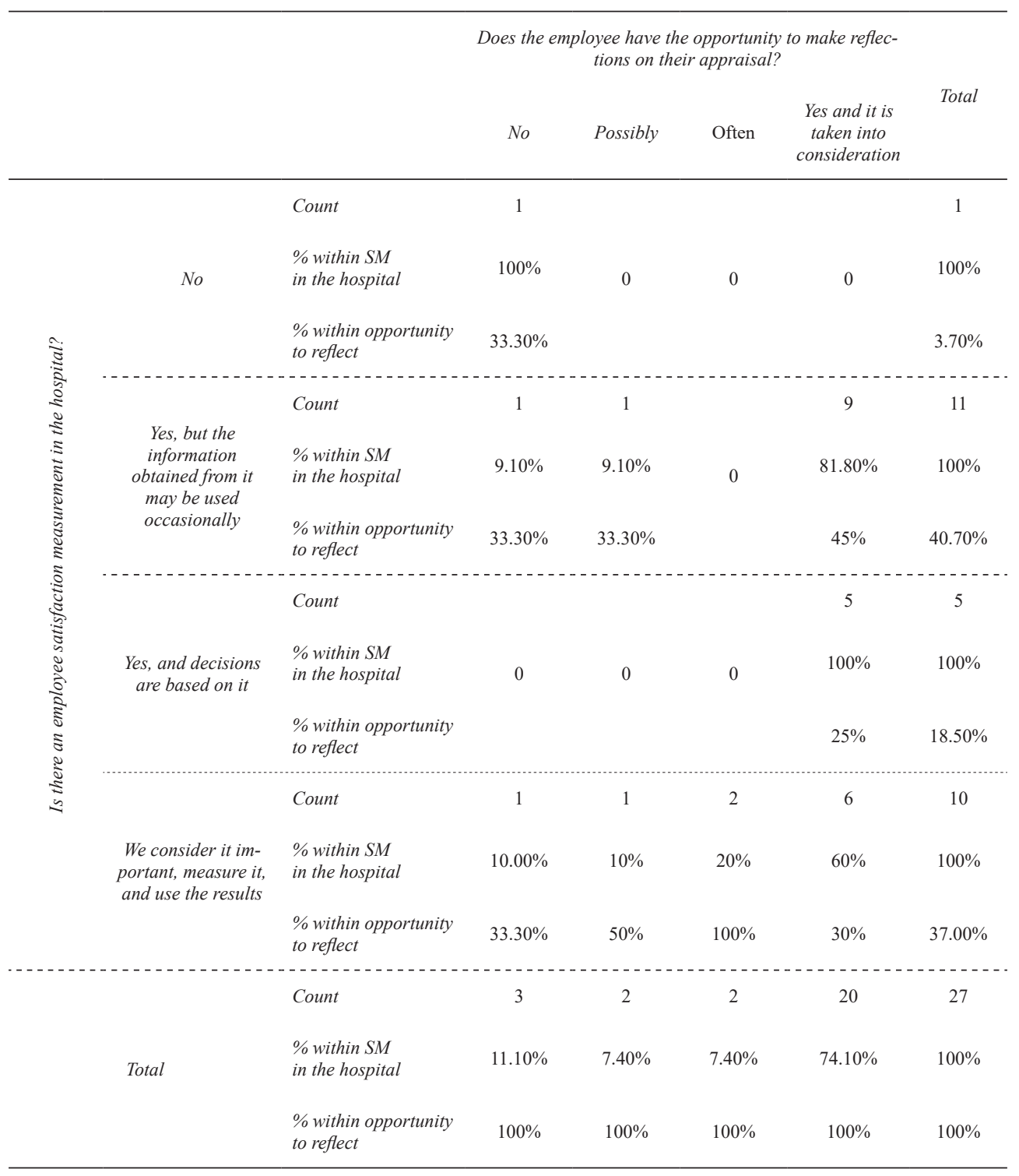


they found the evaluation process and, of course, how much they agreed with the outcome of the appraisal.

We view employee satisfaction measurement as one of the essential components of employee engagement. It is important that the employee has an opportunity to express his or her views in a formal setting. For this reason, we considered it important to examine this issue. In Hungarian hospital practice, employee satisfaction measurement is not meager, being used in a very small percentage, but rather it is used in more than half of it; thus, the measurement practice can be considered remarkable as the obtained results are actually used, albeit to varying degrees. Related to this, the annual employee satisfaction measurement, which is implemented in just over half of the hospitals, is considered adequate. At the same time, this measurement occurs significantly less frequently than annually, which raises certain questions. If an event has occurred that the employee would share, but the possibility of it is much further away in time, it is all the less likely that the employee will share his or her comments about the event. Consideration should be given to linking annual PA and employee satisfaction measurements at a time close to each other.

During the analysis of the participants utilizing the appraisal system, we found that the evaluated workplace leader stands in the first place, which corresponds to the literature's recommendations. This is followed by the evaluated employer and then, with very little difference, the self-appraisal. These three contributors are significant, active features in the evaluation. The person being assessed; i.e. self-appraisal, is a significant element of PAS. It is important to involve the employee in performance planning - part of the performance management cycle already mentioned - because in the view of GYÖKÉR and KRAJCSÁK (2009), goal and work planning fundamentally influence employee satisfaction. This is also supported by the research of NJERI and NASIEKU (2018) which shows that human resource planning has a positive effect on employee performance. In connection with this, it is a welcome fact that the vast majority of the employees receive some form of feedback on the appraisal, in written form, which also presupposes a serious intention on the part of the employer. An important part of appraisals is that the employee has the opportunity to make reflections on the appraisal, and they are often taken into account in nearly three quarters of the cases. Organizational culture influences employee engagement (KRAJCSÁK 2018), and precisely for this reason, it is essential whether employees have the opportunity to make comments in general in the organizational culture. A relaxed, constructive workplace atmosphere can facilitate open communication between employer and employee. This communication can contribute not only to defining performance and clarifying expectations, but also to increasing employee satisfaction.

It was found that where an employee satisfaction measurement exists, an opportunity for the assessee to formulate reflections becomes available. Based on these, it can be stated that the employee remains an active participant in the 
Hungarian performance appraisal systems, that they are involved in the appraisal, and that their views are taken into account. Although not outstanding, the employee is considered a partner in the appraisal of his work. As we do not know whether such research results have been produced in Hungary so far, we hope that we will be able to enrich employee evaluations with valuable aspects.

\section{Limitations and future research}

As mentioned earlier, this investigation has a top-leading perspective; for this reason, employee insights are lacking. In order to fully analyze the employee performance appraisal, it is definitely necessary to involve the employees in the study.

It is also necessary to study the practice of measuring employee satisfaction itself. It may be worth going deeper, e.g., how it is structured, what is included in the employee satisfaction measurement, and the extent to which managers use the information they receive.

\section{References}

Aishwarya M. Patil \& C.S. Dalvi (2019) '720 Degree Performance Appraisal Systems', International Journal of Trend in Scientific Research and Development, Special Issue, Fostering Innovation, Integration and Inclusion Through Interdisciplinary Practices in Management, 4-8 (https://doi.org/10.31142/ ijtsrd23048).

BAKACSI, G. (2015) A szervezeti magatartás alapjai (Budapest: Semmelweis) 12-20. BiBI, M. \& R.A. KHAN (2019) 'Improvement of Employee Performance Through HRM Practices Among Hospital Employees in Karachi, Pakistan', Journal of Humanities and Social Sciences 2019(2), 17-38.

Bokor, A., K. Szőts-Kováts, S. Csillag, K. Bácsi \& R. SzIlas (2009) Emberi Erőforrás Menedzsment (Budapest: AULA) 239-60.

Boncz, I., ed. (2011) Egészségügyi finanszírozási, menedzsment és minőségbiztosítási alapismeretek (Budapest: Medicina) 106-8, retrieved 2 Sep 2021 from http:// publicatio.bibl.u-szeged.hu/17105/1/SandorneSzaboIringoAzegeszsegugyiminosegbiztositasalapjai.pdf.

Gruman, J.A. \& A.M. SAKs (2011) 'Performance Management and Employee Engagement', Human Resource Management Review 21(2), 123-36 (https://doi. org/10.1016/j.hrmr.2010.09.004).

GYÖKÉR I. \& Z. KRAJCSÁK (2009) 'Az alkalmazotti elégedettséget és elkötelezettséget befolyásoló tényezők vizsgálata', Vezetéstudomány - Budapest Management Review 40(ksz) 56-61 (https://doi.org/10.14267/VEZTUD.2009.ksz.09). 
Hermel-StĂnescu, M. (2015) 'The Role of Performance Appraisal in the Context of Performance Management Systems', SEA - Practical Application of Science III, 1(7), retrieved 2 Sep 2021 from https://seaopenresearch.eu/Journals/articles/ SPAS_7_38.pdf.

HsieH, J.Y. (2016) 'Spurious or True? An Exploration of Antecedents and Simultaneity of Job Performance and Job Satisfaction Across the Sectors', Public Personnel Management 45(1) 90-118 (https://doi.org/10.1177/0091026015624714).

JABEen, M. (2011) 'Impact of Performance Appraisal on Employees Motivation', European Journal of Business and Management 3(4), 197-205, retrieved 2 Sep 2021 from https://citeseerx.ist.psu.edu/viewdoc/download?doi $=10.1 .1 .819 .8478 \&$ rep $=$ rep1\&type $=$ pdf.

Jenkins, A. (2005) 'Performance Appraisal Research: A Critical Review of Work on "The Social Context and Politics of Appraisal" ,, (ESSEC) Working Papers DR 05004.

Karitthi, J.W. \& M.O. Ogutu (2016) 'Impact of Strategic Human Resource Management Practices on Organizational Performance (A Case Study of Safaricom)', Human Resource and Leadership Journal 1(1), 1-18 (https://doi.org/10.47941/ hrlj.23).

KAROLIny, M-NÉ. \& J. PoóR, eds. (2010) Emberi erőforrás menedzsment kézikönyv (Budapest: CompLex Kiadó Jogi és Üzletitartalom Szolgáltató Kft) 283-323.

Kıм, T. (2014) Performance Appraisal: Determinants of Public Employee's Acceptance (PhD diss., Newark: The State University of New Jersey).

KrajCsÁK Z. (2018) 'Relationships Between Employee Commitment and Organizational Cultures: A Theoretical Framework', International Journal of Organizational Analysis 26(3) 398-414 (https://doi.org/10.1108/IJOA-05-20171174).

Misiak, S. (2010) 'Ethical System for Employee Performance Appraisal in Practice', Economics \& Sociology 3(2), 101-13, retrieved 2 Sep 2021 from https://www. economics-sociology.eu/files/12\%5b6\%5d.pdf.

Nueri Chege, E. \& T. Nasieku (2018) 'Effect Of Human Resource Management Practises on Employee Performance in Public Hospitals in Kenya: A Case of Nairobi County', International Journal of Social Sciences and Information Technology 5(5), 438-49, retrieved 2 Sep 2021 from https://www.ijssit.com/ main/wp-content/uploads/2019/05/Human-Resource-Management-Practices-On-Employee-Performance-In-Public-Hospitals-In-Kenya.pdf.

Nure, G. (2018) Performance Evaluation of Employees in Hospital Service, retrieved 2 Sep 2021 from https://www.researchgate.net/publication/326543574_PERFORMANCE_EVALUATION_OF_EMPLOYEES_IN_HOSPITAL_SERVICE_Content_content.

Salau, O.P., E.E. ONi-OJo, H. Falola \& J.I. Dirisu (2014) 'Modelling the Relationship Between Performance Appraisal and Organizational Productivity in 
Nigerian Public Sector', International Journal of Research in Management $6(4), 59-74$.

SÁRGA, N.Z. (2016) 'Teljesítményértékelés a Nagykőrösi Rehabilitációs Szakkórház és Rendelöintézet Központi Fizioterápiás Osztályán', IME Interdiszciplináris Magyar Egészségügy 15(8), 11-14.

SÁRGA, N.Z. (2017) 'Eredmény megközelítésű dolgozói teljesítményértékelési rendszerek a Dél-Alföldi Térség kórházaiban', PEME XIV. PhD. - Konferencia, 126-136, retrieved 4 Sep 2021 from https://peme.hu/wp-content/ uploads/2017/04/XIV.-Konferencia-PEME.pdf.

Sing, R.D.R \& S. VAdivelu (2019) 'A Study on Employee Performance Appraisal System in Hospitals - With Respect to Hospitals in Vellore City', Indian Journal of Public Health Research \& Development 10(6), 233-37.

TAKÁCs, S. (2000) A szervezeti kultúra hatása a szervezet teljesitményértékelési gyakorlatára: A vezetöi értékelési magatartás empirikus vizsgálata $(\mathrm{PhD}$ diss., Budapest: Budapesti Közgazdaságtudományi és Államigazgatási Egyetem). 